Cyclooxygenase (COX), existing as the COX-1 and COX2 isoforms, converts arachidonic acid to prostaglandin $\mathrm{H}_{2}$, which is then further metabolized to various prostaglandins. Vascular endothelial growth factor (VEGF) has been shown to play important roles in inflammation and is upregulated by the prostaglandin E series through COX-2 in several cell types. Here, we have investigated the effects of VEGF on the COX isoform expressed in human umbilical vein endothelial cells (HUVEC). The signalling mechanism of the COX isoform expressed in endothelial cells activated with VEGF will be also investigated using the tyrosine kinase inhibitor, genistein, and protein kinase $\mathrm{C}$ inhibitor, staurosporine. The activity of COX2 was assessed by measuring the production of 6-keto-prostaglandin $F_{1 \alpha}$ in the presence of exogenous arachidonic acids $(10 \mu \mathrm{M}, 10 \mathrm{~min})$ by enzyme immunoassay. The expression of COX isoform protein was detected by immunoblot using specific antibodies. Untreated HUVEC contained no COX-2 protein. In HUVEC treated with VEGF $(0.01-50 \mathrm{ng} / \mathrm{ml})$, COX-2 protein, but not COX-1, and COX activity were increased in a dose-dependent manner. In terestingly, the increased COX-2 protein and activity in response to VEGF $(10 \mathrm{ng} / \mathrm{ml})$ was inhibited by the tyrosine kinase inhibitor, genistein $(0.05-5 \mu \mathrm{g} / \mathrm{ml})$, but not by the protein kinase $C$ inhibitor, staurosporine $(0.1-10 \mathrm{ng} / \mathrm{ml})$. Thus, the induction of COX-2 by VEGF in endothelial cells was mediated through protein tyrosine kinase, and the uses of specific COX-2 inhibitors in these conditions, in which VEGF was involved, might have a role.

Key words: Cyclooxygenase, Endothelium, VEGF, Tyrosine kinase, Protein kinase $\mathrm{C}$

\section{The expression of COX-2 in VEGF-treated endothelial cells is mediated through protein tyrosine kinase}

\author{
Pravit Akarasereenont ${ }^{1, \mathrm{CA}}$, Kitirat Techatraisak ${ }^{2}$ \\ Athiwat Thaworn ${ }^{1}$ and Sirikul Chotewuttakorn ${ }^{1}$
}

${ }^{1}$ Department of Pharmacology and ${ }^{2}$ Department of Obstetric and Gynaecology, Faculty of Medicine Siriraj Hospital, Mahidol University, Prannok Road, Bangkok 10700, Thailand

\footnotetext{
${ }^{\mathrm{CA}}$ Corresponding Author

Tel/Fax: +6624197569

E-mail: sipak@mahidol.ac.th
}

\section{Introduction}

Cyclooxygenase (COX) converts arachidonic acid to prostaglandin $\mathrm{H}_{2},{ }^{1}$ which is then further metabolized to various prostaglandins, prostacyclin and thromboxane $\mathrm{A}_{2} .{ }^{2}$ COX exists in at least two isoforms. ${ }^{3}$ COX-1 is expressed constitutively in endothelial cells ${ }^{4}$ and is probably responsible for the production of prostaglandins under physiological conditions. ${ }^{5}$ COX-2 is induced by pro-inflammatory stimuli, including mitogens, ${ }^{6}$ cytokines,${ }^{7,8}$ and bacterial lipopolysaccharide, ${ }^{4}$ in cells in vitro and in inflamed sites in vivo. ${ }^{9}$ However, COX-2 has been shown to be constitutively expressed in some cell types and tissues such as brain, spinal cord, kidneys, reproductive organs, some vascular endothelial cell types and species ${ }^{10}$ including human platelets. ${ }^{11} \mathrm{COX}-2$ has also been shown to be upregulated in some conditions such as atherosclerosis and gastric ulcer associated with Helicobacter pyroli. ${ }^{12,13}$ These are thought to be physiological stress or pathological defense functions of
COX-2, and raised the hypothesis of whether another isoform of COX (COX-3) may exist. ${ }^{14}$

Vascular endothelial growth factor $(\mathrm{VEGF})^{15}$ is a homodimeric $34-42 \mathrm{kDa}$ heparin-binding glycoprotein with potent angiogenic, mitogenic and vascular permeability-enhancing activities specific for endothelial cells. VEGF is expected to play important roles in inflammation and during normal and pathological angiogenesis, a process that is associated with wound healing, embryonic development, and growth and metastasis of solid tumors. ${ }^{16}$ Elevated levels of VEGF have been reported in synovial fluids of rheumatoid arthritis patients and in sera from cancer patients. ${ }^{17-19}$

Recently, COX-2 has been shown to enhance basic fibroblast growth factor-induced angiogenesis through induction of VEGF in rat sponge implants. ${ }^{20}$ We have therefore investigated whether VEGF can activate COX-2 expressed in endothelial cells. The signalling mechanism by which the COX isoform is expressed in endothelial cells activated with VEGF 
will be also investigated using the tyrosine kinase inhibitor, genistein, and protein kinase $\mathrm{C}$ inhibitor, staurosporine.

\section{Materials and methods}

\section{Cell culture}

Human umbilical vein endothelial cells (HUVEC) were obtained from babies born to normal pregnant women as previously described. ${ }^{21}$ All patients gave written informed consent. HUVEC were cultured in 96-well plates with human endothelial-SFM basal growth medium (Gib Thai, Bangkok, Thailand) containing $10 \%$ foetal calf serum (Gib Thai), $100 \mathrm{U} / \mathrm{ml}$ of penicillin $G$ sodium and $100 \mu \mathrm{g} / \mathrm{ml}$ of streptomycin. Cells were incubated at $37^{\circ} \mathrm{C}$ in a humidified incubator and grown to confluence before use.

\section{Measurement of the COX activity}

Confluent HUVEC were gently washed twice with phosphate-buffered saline (PBS) and incubated with human endothelial-SFM basal growth medium ( $200 \mu \mathrm{l} /$ well) with no addition, VEGF $(0.01,0.1,1$ or $10 \mathrm{ng} / \mathrm{ml}$ ) alone, genistein (a protein tyrosine kinase inhibitor; $5 \mu \mathrm{g} / \mathrm{ml}$ ) alone, staurosporine (a protein kinase C inhibitor; $10 \mathrm{ng} / \mathrm{ml})$ alone, orVEGF $(10 \mathrm{ng} / \mathrm{ml})$ + genistein $(0.05,0.5$ or $5 \mu \mathrm{g} / \mathrm{ml})$ or staurosporin $(0.1$, 1 or $10 \mathrm{ng} / \mathrm{ml}$ ) for $24 \mathrm{~h}$. After this, the medium was removed and washed twice with PBS. COX activity was measured by the production of 6-keto-prostaglandin (PG) $F_{1 \alpha}$ (a stable metabolite of $\mathrm{PGI}_{2}$ that is the major COX metabolite in endothelial cells) in the replaced fresh medium containing exogenous arachidonic acid (10 $\mu \mathrm{M}$ for $10 \mathrm{~min}$ ) using an enzyme immunoassay (EIA kit, Amersham, Buckingham, UK).

\section{Immunoblot (Western blot) analysis}

HUVEC that were untreated (control), treated with genistein $(5 \mu \mathrm{g} / \mathrm{ml})$ alone, staurosporine $(10 \mathrm{ng} / \mathrm{ml})$ alone, VEGF $(0.01-50 \mathrm{ng} / \mathrm{ml})$ alone, VEGF $(10 \mathrm{ng} / \mathrm{ml})$ + genistein $(5 \mu \mathrm{g} / \mathrm{ml})$ or VEGF $(10 \mathrm{ng} / \mathrm{ml})+$ staurosporine $(10 \mathrm{ng} / \mathrm{ml})$ were cultured in six-well plates $\left(37^{\circ} \mathrm{C}\right.$, for $\left.24 \mathrm{~h}\right)$. After incubation, cells were extracted and a specific monoclonal COX-1 or COX-2 antibody was used to detect the expression of COX isoform as previously described. ${ }^{22}$

\section{Measurement of cell viability}

Cell respiration, an indicator of cell viability, was assessed by the mitochondrial dependent reduction of 3-(4,5-dimethylthiazol-2-yl)-2,5-diphenyltetrazolium bromide (MTT) to formazan. ${ }^{23}$ At the end of each experiment, cells in 96-well plates were incubated $\left(37^{\circ} \mathrm{C}, 1 \mathrm{~h}\right)$ with MTT $(0.2 \mathrm{mg} / \mathrm{ml})$ dissolved in culture medium, after which time the medium was removed by aspiration and cells were solubilized in DMSO (200 $\mu 1$ in each well). The extent of reduction of MTT to formazan within cells was quantitated by the measurement of optical density at $650 \mathrm{~nm}$ using a microplate reader (BIORAD, California, USA).

\section{Statistical analysis}

Results are shown as mean \pm standard error of the mean from triplicate determinations (wells) from at least three separate experimental days $(n=9)$. Student's paired or unpaired $t$-tests were used as appropriate to determine the significance of differences between means, and $p<0.05$ was taken as statistically significant.

\section{Materials}

Staurosporine, genistein, dimethyl sulfoxide (DMSO), PBS ( $\mathrm{pH}$ 7.4), Trisma base, ethylenediamine tetraacetic acid, triton X-100, phenylmethylsulphonyl fluoride, pepstatin A, leupeptin, glycerol, bromphenol blue, 2-mercaptoethanol, sodium dodecyl sulphate, anti-rabbit IgG antibody, goat IgG, premixed BCIP/ NBT solution, MTT, penicillin G sodium and streptomycin were supplied by Sigma Chemical Company (St. Louis, MO, USA). 6-keto-PGF ${ }_{1 \alpha}$ assay kits were purchased from Amersham (USA). Human endothelialSFM basal growth medium and foetal calf serum were obtained from GibThai. A specific monoclonal COX-1 (human) or COX-2 (human) antibody was obtained from Cayman Chemical Company (Sapphire, Australia). Recombinant human VEGF was purchased from R\&D (Minneapolis, MN, USA). Pure nitrocellulose membrane $(0.45 \mu \mathrm{m})$ and filter paper were purchased from BIO-RAD.

\section{Results}

The effects of VEGF on the COX isoform expressed in HUVEC

Control untreated cells contained COX-1 protein but not COX-2 protein (Figs. 1 and 2, lane 1). The amount of COX-1 protein expressed in HUVEC treated with VEGF $(0.01,0.1,1,10$ or $50 \mathrm{ng} / \mathrm{ml})$ did not change when compared with control untreated cells at $24 \mathrm{~h}$ (Fig. 2). Interestingly, COX-2 protein was induced in HUVEC treated with VEGF $(0.01,0.1,1,10$ or $50 \mathrm{ng}$ / $\mathrm{ml}$ ) in a dose-dependent manner (Fig. 1).

\section{The effects of VEGF on COX activity in HUVEC}

In HUVEC treated with VEGF $(0.01,0.1,1$ or $10 \mathrm{ng}$ / $\mathrm{ml}$ ), COX activity as measured by the production of 6-keto-PGF ${ }_{1 \alpha}$ in the presence of exogenous arachidonic acids ( $10 \mu \mathrm{M}$ for $10 \mathrm{~min})$ was also increased in a dose-dependent manner. The increased COX activity in VEGF-treated HUVEC was significant at $0.1 \mathrm{ng} / \mathrm{ml}$ of VEGF $(p<0.05, n=12$; Fig. 3 ). 


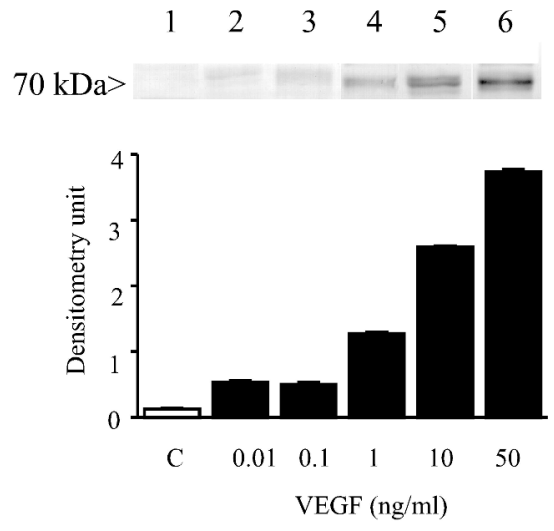

FIG. 1. The effects of VEGF on COX-2 expressed in HUVEC. COX-2 was detected by Western blots using specific antibodies to COX-2 in cell extracts of HUVEC treated with no addition (lane 1 ) or with VEGF $(0.01,0.1,1,10$ or $50 \mathrm{ng} / \mathrm{ml}$; lanes 2-6) for $24 \mathrm{~h}$. Equal amounts of protein $(20 \mu \mathrm{g} /$ lane $)$ were loaded in each lanes. Similar results were obtained with cell extracts from three separate batches of cells. The significant differences between each band were compared by scanner densitometry using an image one-dimensional program (densitometry unit).

VEGF $(0.01,0.1,1$ or $10 \mathrm{ng} / \mathrm{ml})$ did not affect cell viability when compared with the control untreated cells over a $24 \mathrm{~h}$ incubation period $(\phi>0.05, n=$ 12).

The effects of genistein (tyrosine kinase inhibitor) and staurosporine (protein kinase $C$ inhibitor) on COX activity in VEGF-treated HUVEC

Interestingly, the increased COX activity as measured by the production of 6-keto-PGF ${ }_{1 \alpha}$ in the presence of

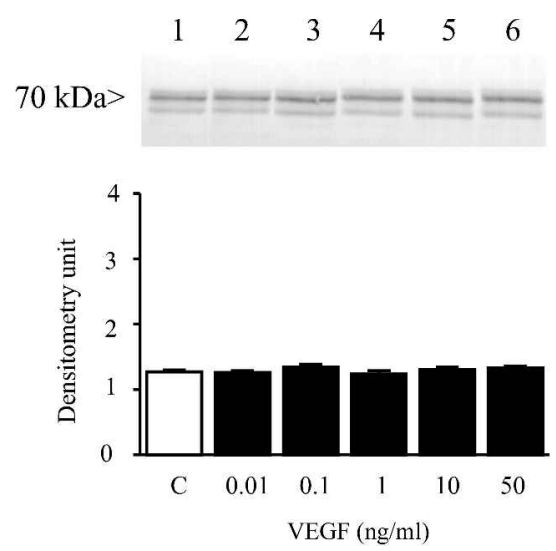

FIG. 2. The effects of VEGF on COX-1 expressed in HUVEC. COX-1 was detected by Western blots using specific antibodies to COX-2 in cell extracts of HUVEC treated with no addition (lane 1) or with VEGF $(0.01,0.1,1,10$ or $50 \mathrm{ng} / \mathrm{ml}$; lanes 2-6) for $24 \mathrm{~h}$. Equal amounts of protein $(20 \mu \mathrm{g} / \mathrm{lane})$ were loaded in each lane. Similar results were obtained with cell extracts from three separate batches of cells. The significant differences between each band were compared by scanner densitometry using an image one-dimensional program (densitometry unit).

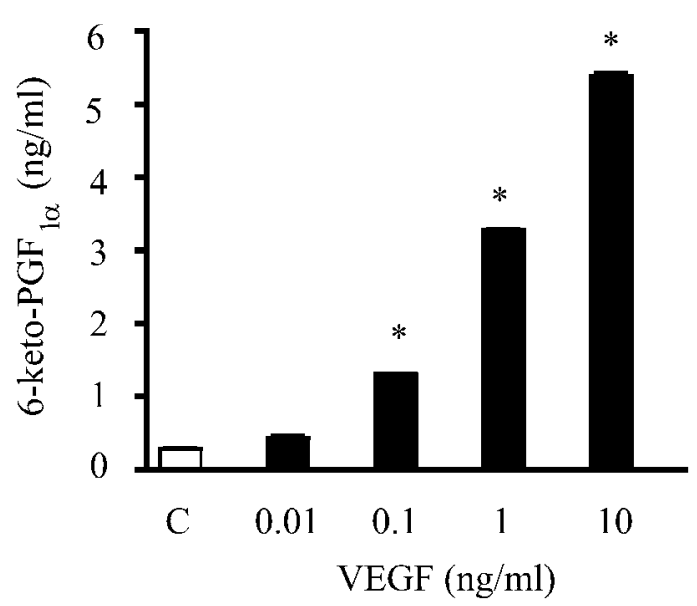

FIG. 3. Dose-dependent effects of VEGF $(0.01-10 \mathrm{ng} / \mathrm{ml})$ on COX activity in HUVEC. COX activity was measured by the formation of 6-keto-PGF $F_{1 \alpha}$ in the presence of exogenous arachidonic acid $(10 \mu \mathrm{M}, 10 \mathrm{~min})$. Data are expressed as mean \pm standard error of the mean of 12 determinations from at least four separate experimental days. ${ }^{*} p<0.05$ when compared with untreated HUVEC at $24 \mathrm{~h}$ (C).

exogenous arachidonic acids $(10 \mu \mathrm{M}$ for $10 \mathrm{~min})$ in HUVEC activated with VEGF $(10 \mathrm{ng} / \mathrm{ml})$ was inhibited by genistein $(0.05,0.5$, or $5 \mu \mathrm{g} / \mathrm{ml}$, at $24 \mathrm{~h})$ in a dosedependent manner (Fig. 4A) but not by staurosporine $(0.1,1$, or $10 \mathrm{ng} / \mathrm{ml}$, at $24 \mathrm{~h}$; Fig. 4B). The inhibition of increased COX activity in VEGF-treated HUVEC was significant at $0.5 \mu \mathrm{g} / \mathrm{ml}$ of genistein $(p<0.05, n=12$; Fig. $4 \mathrm{~A})$. Moreover, the production of 6-keto-PGF $1 \alpha$ in untreated HUVEC was not affected when cells were co-incubated with genistein alone $(5 \mu \mathrm{g} / \mathrm{ml}$; Fig. 4A) or staurosporine alone $(10 \mathrm{ng} / \mathrm{ml}$; Fig. $4 \mathrm{~B})$ for $24 \mathrm{~h}$.

Genistein $(0.05-5 \mu \mathrm{g} / \mathrm{ml})$ and staurosporine $(0.1-10 \mathrm{ng} / \mathrm{ml})$ did not affect cell viability when compared with the control untreated cells over a $24 \mathrm{~h}$ incubation period (all $>90 \%$ of untreated cells).

The effects of genistein (tyrosine kinase inhibitor) and staurosporine (protein kinase C inhibitor) on the COX isoform expressed in VEGF-treated HUVEC

The induction of COX-2 protein by VEGF $(10 \mathrm{ng} / \mathrm{ml})$ in HUVEC was inhibited by genistein $(5 \mu \mathrm{g} / \mathrm{ml}$, at $24 \mathrm{~h})$ but not by staurosporine $(10 \mathrm{ng} / \mathrm{ml}$, at $24 \mathrm{~h})$ (Fig. 5). The amount of COX-1 protein expressed in HUVEC treated with genistein $(5 \mu \mathrm{g} / \mathrm{ml})$ alone, staurosporine $(10 \mathrm{ng} / \mathrm{ml})$ alone, VEGF + genistein $(5 \mu \mathrm{g} / \mathrm{ml})$ or VEGF + staurosporine $(10 \mathrm{ng} / \mathrm{ml})$ at $24 \mathrm{~h}$ was not changed when compared with untreated control cells (Fig. 6).

\section{Discussion}

In the present paper, we have shown that VEGF could induce COX-2 protein expressed in HUVEC 
A
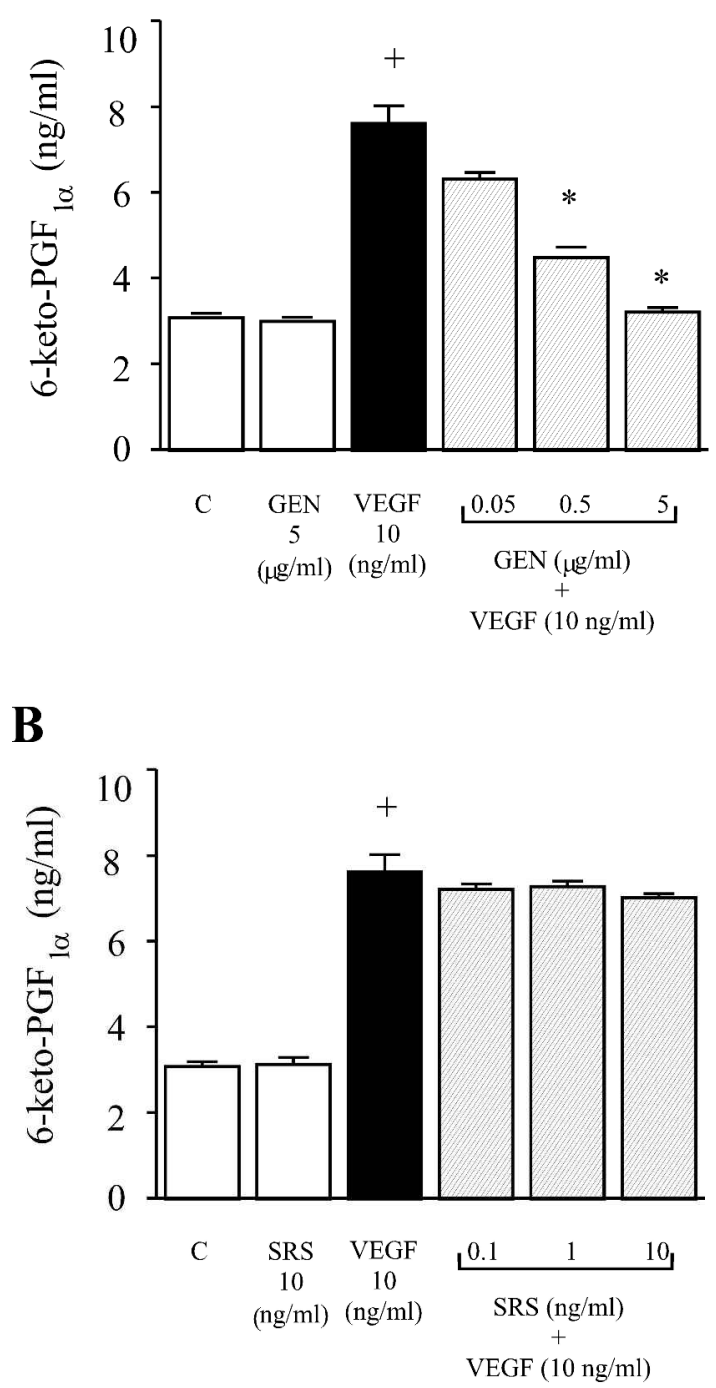

FIG. 4. The effects of (A) genistein (GEN) $(0.05-5 \mu \mathrm{g} / \mathrm{ml}$ ) and (B) staurosporine (SRS) $(0.1-10 \mathrm{ng} / \mathrm{ml})$ on COX activity in HUVEC treated with VEGF $(10 \mathrm{ng} / \mathrm{ml})$ for $24 \mathrm{~h}$. COX activity was measured by the formation of 6-keto-PGF ${ }_{1 \alpha}$ in the presence of exogenous arachidonic acid $(10 \mu \mathrm{M}, 10 \mathrm{~min})$. Data are expressed as mean \pm standard error of the mean of 12 determinations from at least four separate experimental days. ${ }^{*} p<0.05$ when compared with VEGF-treated HUVEC at $24 \mathrm{~h} ;{ }^{+} p<0.05$ when compared with untreated HUVEC at $24 \mathrm{~h}$ (C).

while the amount of COX-1 protein expression was not affected. VEGF also increased COX activity as measured by the production of 6-keto-PGF ${ }_{1 \alpha}$ (a stable metabolite of $\mathrm{PGI}_{2}$ ) in a dose-dependent manner. This increased COX activity was dependent on COX-2; Fig. 3 clearly shows that VEGF increased 6-keto-PGF ${ }_{1 \alpha}$ production in the presence of exogenous arachidonic acid in a dose-dependent manner, while COX-2 protein only (not COX-1 protein) was induced (Figs. 1 and 2). Moreover, the increased COX activity and COX-2 protein in VEGF-treated HUVEC were decreased when cells were co-incubated with genistein (tyrosine kinase inhibitor; Figs.
$70 \mathrm{kDa}>$

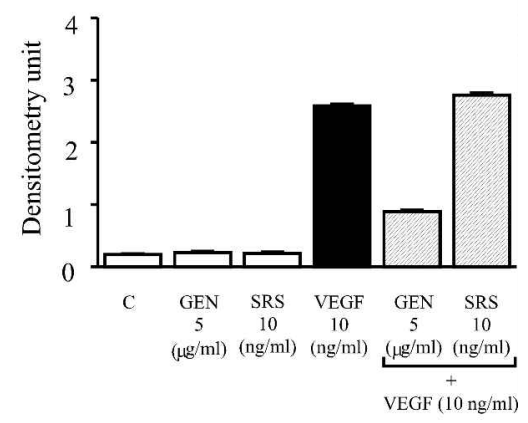

FIG. 5. The effects of genistein (GEN) and staurosporine (SRS) on COX-2 expressed in VEGF-treated HUVEC. COX-2 was detected by Western blots using specific antibodies to COX-2 in cell extracts of HUVEC treated with no addition (lane 1), with genistein $(5 \mu \mathrm{g} / \mathrm{ml})$ alone (lane 2), with staurosporine $(10 \mathrm{ng} / \mathrm{ml})$ alone (lane 3$)$, with VEGF $(10 \mathrm{ng} / \mathrm{ml})$ alone (lane 4), with VEGF $(10 \mathrm{ng} / \mathrm{ml})+$ genistein $(5 \mu \mathrm{g} / \mathrm{ml}$; lane 5) or with VEGF $(10 \mathrm{ng} / \mathrm{ml})+$ staurosporine $(10 \mathrm{ng} / \mathrm{ml}$; lane 6) for $24 \mathrm{~h}$. Equal amounts of protein $(20 \mu \mathrm{g} / \mathrm{lane})$ were loaded in each lane. Similar results were obtained with cell extracts from three separate batches of cells. The significant differences between each band were compared by scanner densitometry using an image one-dimensional program (densitometry unit).

4 and 5) while COX-1 protein was unaffected (Fig. 6). However, the increased COX activity and COX-2 protein in VEGF-treated HUVEC were not changed when cells were co-incubated with staurosporine

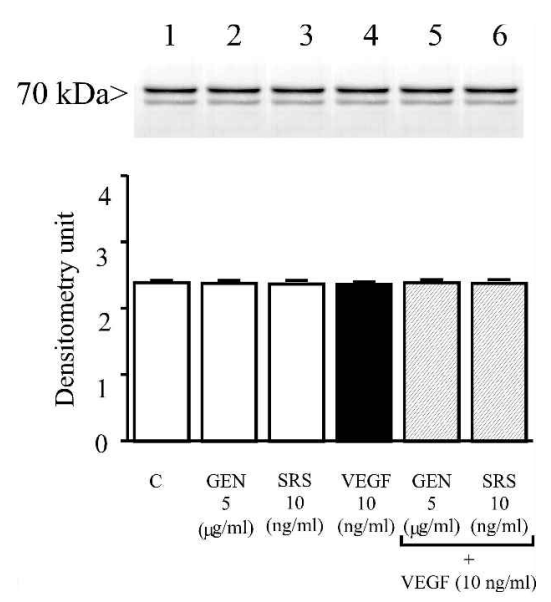

FIG. 6. The effects of genistein (GEN) and staurosporine (SRS) on COX-1 expressed in VEGF-treated HUVEC. COX-1 was detected by Western blots using specific antibodies to COX- 1 in cell extracts of HUVEC treated with no addition (lane 1), with genistein $(5 \mu \mathrm{g} / \mathrm{ml})$ alone (lane 2), with staurosporine $(10 \mathrm{ng} / \mathrm{ml})$ alone (lane 3$)$, with VEGF $(10 \mathrm{ng} / \mathrm{ml})$ alone (lane 4), with VEGF $(10 \mathrm{ng} / \mathrm{ml})+$ genistein $(5 \mu \mathrm{g} / \mathrm{ml}$; lane 5) or with VEGF $(10 \mathrm{ng} / \mathrm{ml})+$ staurosporine $(10 \mathrm{ng} / \mathrm{ml}$; lane 6) for $24 \mathrm{~h}$. Equal amounts of protein $(20 \mu \mathrm{g} / \mathrm{lane})$ were loaded in each lane. Similar results were obtained with cell extracts from three separate batches of cells. The significant differences between each band were compared by scanner densitometry using an image one-dimensional program (densitometry unit). 
(protein kinase $\mathrm{C}$ inhibitor; Figs. 4 and 5). The COX1 protein was also unaffected when cells were co-incubated with staurosporin (Fig. 6). Therefore, our results showed that the induction of COX-2 in HUVEC treated with VEGF was mediated through protein tyrosine kinase but not by protein kinase $\mathrm{C}$.

VEGF is an endothelium-specific peptide that potently stimulates angiogenesis, vasodilation and microvascular hyperpermeability. Previous study showed that VEGF rapidly increased phosphorylation and activity of cytosolic PLA $\mathrm{P}_{2}$, and stimulated release of arachidonic acid in HUVEC resulted in prostaglandin production. ${ }^{24}$ However, it was not shown whether the COX isoform mediates these effects. Therefore, the uses of exogenous arachidonic acid as substrates will help to evaluate COX enzyme directly. Recently, it has been shown that VEGF upregulates COX-1 in bovine aortic endothelial cells and HUVEC. ${ }^{25}$ In contrast, here, our results showed that VEGF directly increased COX activity in HUVEC through the induction of COX-2. However, the amount of COX-1 protein expressed in HUVEC treated with VEGF did not change when compared with untreated HUVEC. A major concern of the different results was the cross-reactivity and source of the antibodies used. For COX-1 detection, Bryant et al. ${ }^{25}$ used a $1: 7500$ dilution of anti-sheep COX-1 raised to rabbit while we used a $1: 2000$ dilution of specific COX-1 monoclonal antibody (clone CX-111). For COX-2 detection, Bryant et al. ${ }^{25}$ used a $1: 10,000$ dilution of anti-human COX-2 raised to rabbit while we used a $1: 2000$ dilution of specific COX-2 monoclonal antibody. The other explanation was whether another COX isoform (COX-3) may exist. However, these points could be argued and await elucidation.

Moreover, we also showed that the increased COX activity and COX-2 protein in HUVEC treated with VEGF was mediated through protein tyrosine kinase, but not protein kinase C (Figs. 4 and 5). These findings were correlated with previous studies showing that VEGF receptors on endothelial cells were acted via protein tyrosine kinase ${ }^{26-28}$ and the induction of COX-2 in endothelial cells by several mitogens was mediated through protein tyrosine kinase. ${ }^{29}$ Therefore, the downstream regulation of PG production in HUVEC activated with VEGF was affected at several sites such as COX-2 protein, tyrosine phosphorylation and phospholipase $\mathbf{A}_{2}$.

In summary, our studies are the first to show that COX-2 can be induced in HUVEC treated with VEGF through protein tyrosine kinase. VEGF is known to be involved in pathological conditions such as inflammation, atherosclerosis and carcinogenesis. ${ }^{16}$ Thus, the uses of specific COX-2 inhibitors in these conditions, in which VEGF was involved, might have a role..$^{30-32}$
ACKNOWLEDGEMENTS. This work was supported by a Grant from Thai Research Fund to P.A.

\section{References}

1. Hamberg M, Svensson J, Samuelsson B. Prostaglandin endoperoxides. A new concept concerning the mode of action and release of prostaglandins. Proc Natl Acad Sci USA 1974; 71: 3824-3828.

2. Smith WL, Marnett IJ. Prostaglandin endoperoxide synthase: structure and catalysis. Biochim Biophys Acta 1991; 1083: 1-17.

3. Xie WL, Chipman JG, Robertson DL, Erikson RL, Simmons DL. Expression of a mitogen-responsive gene encoding prostaglandin synthase is regulated by mRNA splicing. Proc Natl Acad Sci USA 1991; 88 : $2692-2696$

4. Akarasereenont P, Mitchell JA, Bakhle YS, Thiemermann C, Vane JR. Comparison of the induction of cyclooxygenase and nitric oxide synthase by endotoxin in endothelial cells and macrophages. Eur $J$ Pharmacol 1995; 273: 121-128.

5. Vane JR. The Croonian Lecture, 1993. The endothelium: maestro of the blood circulation. Philos Trans $R$ Soc London B Biol Sci 1994; 343 : 225-246.

6. O'Banion MK, Winn VD, Young DA. cDNA cloning and functional activity of a glucocorticoid-regulated inflammatory cyclooxygenase. Proc Natl Acad Sci USA 1992; 89: 4888-4892.

7. Maier JAM, Hla T, Maciag T. Cyclooxygenase is an immediate-early gene induced by interleukin- 1 in human endothelial cells. J Biol Chem 1990; 265: 10805-10808.

8. Lee SH, Soyoola E, Chanmugam P, Hart S, Sun W, Zhong H, Liou S, Simmons DL, Hwang D. Selective expression of mitogen-inducible cyclooxygenase in macrophages stimulated with lipopolysaccharide. $J$ Biol Chem 1992; 267: 25934-25938.

9. Vane JR, Mitchell JA, Appleton I, Tomlinson A, Bishop-Baily D, Croxtall J, Willoughby D. Inducible isoforms of cyclooxygenase and nitric-oxide synthase in inflammation. Proc Natl Acad Sci USA 1994; 91: 2046-2050.

10. Dubois RN, Abramson SB, Crofford L, Cupta RA, Simon LS, van de Puttle LBA, Lipsky PE. Cyclooxygenase in biology and disease. FASEB J 1999; 12: 1063-1073.

11. Weber AA, Zimmerman KC, Meyer-Kirchrath J, Schror K. Cyclooxygenase-2 in human platelets as a possible factor in aspirin resistance. Lancet 1999; 353 : 900.

12. Schunbeck U, Sukhova GK, Graber P, Coulter S, Libby P. Augmented expression of cyclooxygenase-2 in human atherosclerotic lesions. Am J Pathol 1999; 155: 1281-1291.

13. Franco L, Talamini G, Carra G, Doria D. Expression of COX-1, COX-2, and inducible nitric oxide synthase protein in human gastric antrum with Helicobacter pylori infection. Prostaglandins Other Lipid Mediat 1999; 58: 9-17.

14. Willoughby DA, Moore AR, Colville-Nash PR. COX-1, COX-2, and COX-3 and the future treatment of chronic inflammatory disease. Lancet 2000; 355: 646-648

15. Ferrara N, Houck K, Jakeman L, Leung DW. Molecular and biological properties of the vascular endothelial growth factor family of proteins. Endocr Rev 1992; 13: 18-32.

16. Ferrara N. Vascular endothelial growth factor and the regulation of angiogenesis. Recent Progr Horm Res 2000: 55; 15-35.

17. Senger DR, Van de Water L, Brown LF, Nagy JA, Yeo KT, Yeo TK, Berse B, Jackman RW, Dvorak AM, Dvorak HF. Vascular permeability factor (VPF, VEGF) in tumor biology. Cancer Metastasis Rev 1993; 12: 303-324.

18. Koch AE, Harlow LA, Haines GK, Amento EP, Unemori EN, Wong WL, Pope RM, Ferrara N. Vascular endothelial growth factor. A cytokine modulating endothelial function in rheumatoid arthritis. J Immunol 1994; 152: 4149-4156.

19. Kondo S, Asano M, Matsuo K, Ohmori I, Suzuki H. Vascular endothelial growth factor/vascular permeability factor is detectable in the sera of tumor-bearing mice and cancer patients. Biochim Biophys Acta 1994; 1221: 211-214.

20. Majima M, Hayashi I, Muramatsu M, Katada J, Yamashina S, Katori M. Cyclo-oxygenase-2 enhances basic fibroblast growth factor-induced angiogenesis through induction of vascular endothelial growth factor in rat sponge implants. Br J Pharmacol 2000; 130: 641-649.

21. Jaffe EA, Nachman RL, Becker CG, Minick CR. Culture of human endothelial cells derived from umbilical veins: identification by morphologic and immunologic criteria. J Clin Invest 1973; 52: 2745-2756.

22. Akarasereenont $P$, Techatraisak K, Thaworn A, Chotewuttakorn $S$. The expression of cyclooxygenase- 2 in human umbilical vein endothelial cell culture from preeclampsia. J Med Assoc Thai 1999; 82: 167-172.

23. Mosmann T. Rapid colorimetric assay for cellular growth and survival: Application to proliferation and cytotoxicity assays. I Immunol Methods 1983; 65: 55-63.

24. Wheeler-Jones C, Abu-Ghazaleh R, Cospedal R, Houliston RA, Martin J, Zachary I. Vascular endothelial growth factor stimulates prostacyclin production and activation of cytosolic phospholipase $\mathrm{A}_{2}$ in endothelial cells via p42/p44 mitogen-activated protein kinase. FEBS Lett 1997; 420 : 28-32. 
25. Bryant CE, Appleton I, Mitchell JA. Vascular endothelial growth factor upregulates constitutive cyclooxygenase 1 in primary bovine and human endothelial cells. Life Sci 1998; 62: 2195-2201.

26. Abedi H, Zachary I. Vascular endothelial growth factor stimulates tyrosine phosphorylation and recruitment to new focal adhesions of focal adhesion kinase and paxillin in endothelial cells. J Biol Chem 1997; 272: 15442-15451.

27. de Vries C, Escobedo JA, Ueno H, Houck K, Ferrara N, Williams LT. The fms-like tyrosine kinase, a receptor for vascular endothelial growth factor. Science 1992; 255: 989-991.

28. Terman BI, Dougher-Vermazen M, Carrion ME, Dimitrov D, Armellino DC, Gospodarowicz D, Bohlen P. Identification of the KDR tyrosine kinase as a receptor for vascular endothelial cell growth factor. Biochem Biophys Res Commun 1992; 187: 1579-1586.

29. Akarasereenont P, Bakhle YS, Thiemermann C, Vane JR. Cytokines mediate the induction of cyclooxygenase- 2 by activating tyrosine kinase in bovine aortic endothelial cells stimulated by bacterial lipopolysaccharide. Br J Pharmacol 1995; 115: 401-408.

30. Liu XH, Kirschenbaum A, Yao S, Lee R, Holland JF, Levine AC. Inhibition of cyclooxygenase- 2 suppresses angiogenesis and the growth of prostate cancer in vivo. J Urol 2000; 164: 820-825.

31. Masferrer JL, Koki A, Seibert K. COX-2 inhibitors. A new class of antiangiogenic agents. Ann NY Acad Sci 1999; 889: 84-86.

32. Williams CS, Tsujii M, Reese J, Dey SK, DuBois RN. Host cyclooxygenase2 modulates carcinoma growth. J Clin Invest 2000; 105: 1589-1594.

\section{Received 25 September 2001}

Accepted 31 October 2001 


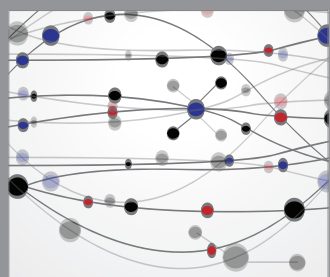

The Scientific World Journal
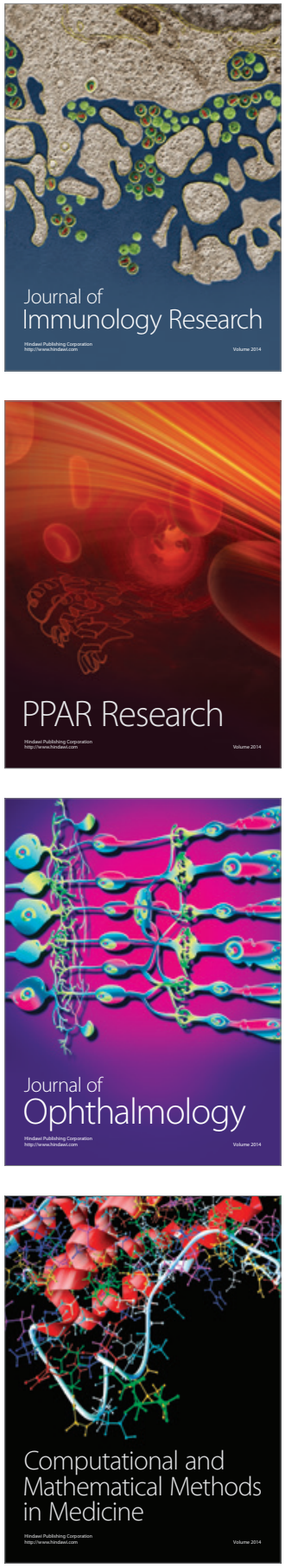

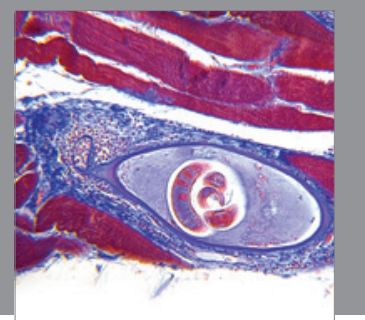

Gastroenterology

Research and Practice
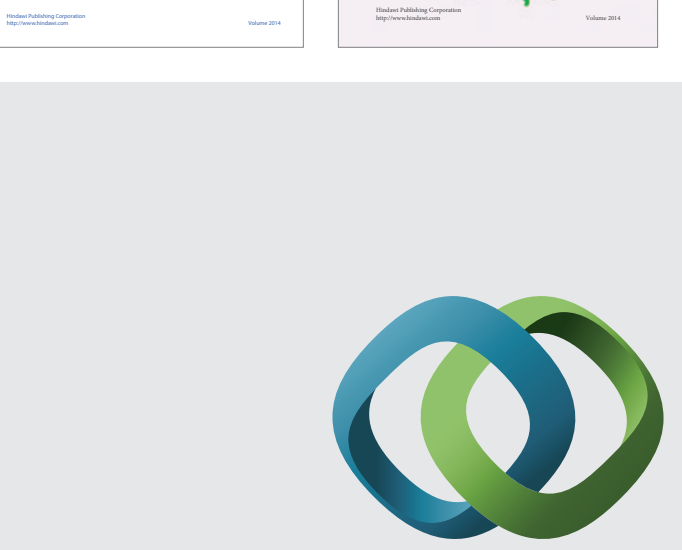

\section{Hindawi}

Submit your manuscripts at

http://www.hindawi.com
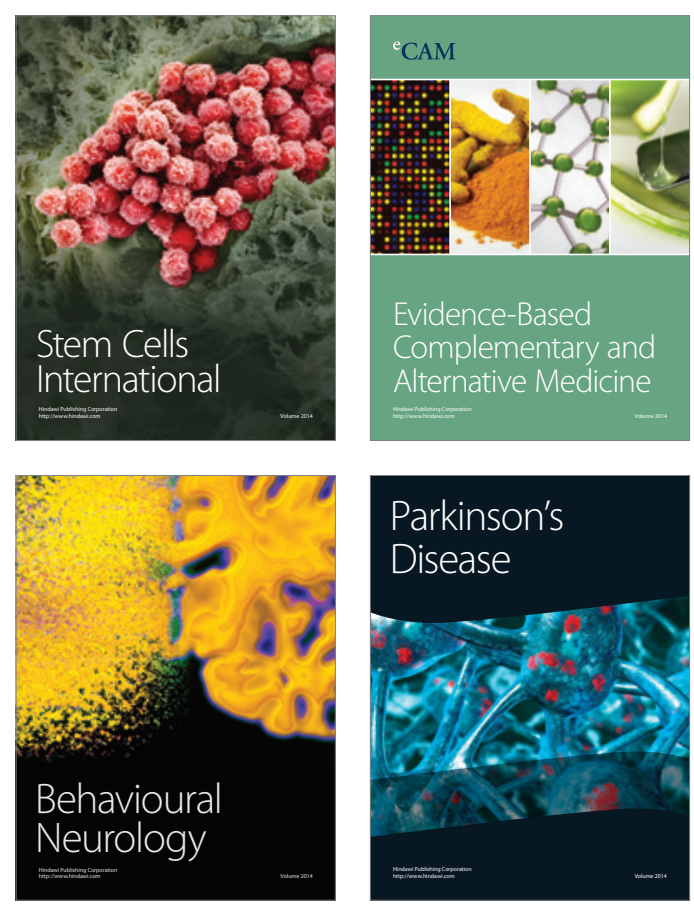

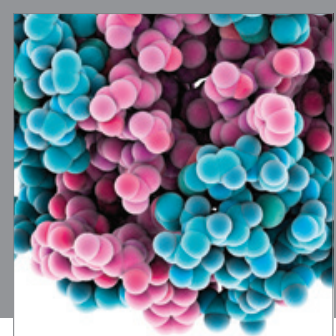

Journal of
Diabetes Research

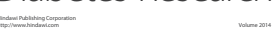

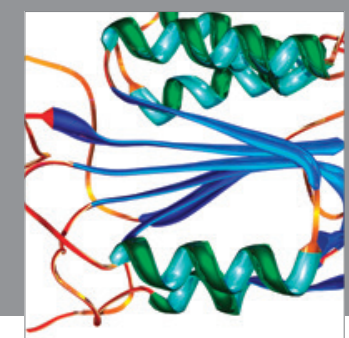

Disease Markers
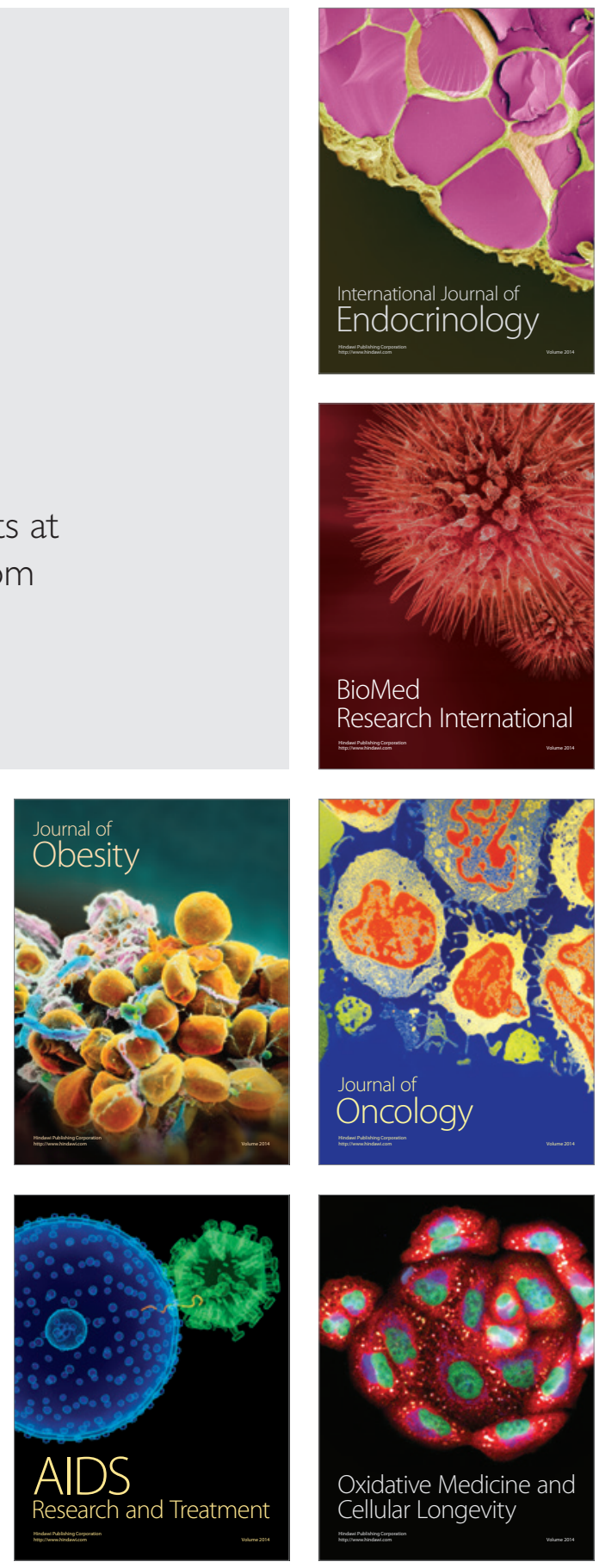